DOI: $\underline{10.20472 / T E .2016 .4 .1 .005 ~}$

\title{
TRENDS IN CURRICULAR ISSUES AND TEACHER EDUCATION IN NIGERIA: RETROSPECT AND PROSPECTS
}

\section{MARIAN OLUYEMISI ODUNAIYA}

\begin{abstract}
:
Education in Nigeria in the past was centered on recitation, use of conversation, lecture and questioning method to teach students new information and concepts.Traditionally, the emphases on our curricular has been on defined knowledge to be acquired with less attention on the development of skills, conscious articulation of the other remaining areas of learning behaviour, attitudes and values and finally learning to learn. This paper therefore examines the trends in curricular issues of teacher education programme in Nigeria. It investigates the nature of teacher education, its impacts, problems, directions as well as prospects for future development of the curricular issues.
\end{abstract}

\section{Keywords:}

Teacher Education, Curricular Issues, Innovations, critical thinking

JEL Classification: 129

\section{Authors:}

MARIAN OLUYEMISI ODUNAIYA, Federal College of Education (Technical) Akoka, Nigeria, Email: marianyem@yahoo.com

\section{Citation:}

MARIAN OLUYEMISI ODUNAIYA (2016). TRENDS IN CURRICULAR ISSUES AND TEACHER EDUCATION IN NIGERIA: RETROSPECT AND PROSPECTS. International Journal of Teaching and Education, Vol. IV(1), pp. 54-63., 10.20472/TE.2016.4.1.005 


\section{Introduction}

Curriculum has been variously defined in the past in a variety of ways. Some regarded it as a plan, an educational programme, learning experiences etc.

It is in this light that Smith (2000) defined curriculum as what happens in the classroom including the transmission of information; attempt to achieve certain ends, process of interactions of students, teachers, knowledge and mileu and action that are committed in classrooms.

Generally speaking curriculum can be seen as the sum total of all the subjects taught in a school and which essentially should contain four main components of; objectives, content or subject matter, the method or ways of passing on the knowledge and lastly evaluation or assessment.

However, Obanya and Fadoju (2008, p. 30) emphasize that curriculum is a process that involves translating the nations broad educational goals into down-to-earth realities and of making formal choices on how the realities can be implemented to ensure that the ultimate goal of education derived from the nation overall development goals are attained through the concrete activities of the schools and the entire education system.

The success of any educational process in terms of quality depends largely on the regular supply of teachers in enough quantity and quality. Ibukun (2004) stated that the quality of human resources in form of teachers often dictates the extent of the effectiveness of the educational programmes.

\section{Statement of the problem}

It has been observed that teaching and learning ought to have moved beyond teachers giving all information to the students in the classroom to use of social media and other teaching tools as well as use of research, innovations on the part of students with high critical thinking. 


\section{Nature of Teacher Education}

Teacher education can be defined as a body of knowledge, a subject matter designed to equip the prospective teacher with the adequate pedagogical knowledge and skills with the ability of changing the learners' behavior. Dosumu (2003). The Wikipedia also defined it as policies and procedures designed to equip prospective teachers with knowledge, attitudes, behaviours and skills they require to perform their tasks effectively in the classroom, school and the wider community.

Teacher education globally is divided into the following stages;

- Initial Teacher Training / Education

- Induction

Continuing Professional Development

\section{Purpose of Teacher Education}

According to the National policy on education (1998), the following are the purpose of teacher education.

To produce highly motivated conscientious and efficient classroom teachers for all levels of our education system, to encourage further spirit of enquiry and creativity in teachers,to help teachers to fit into the social life of the community and society at large and to enhance their commitment to national objectives, to provide teachers with intellectual and professional background adequate for their assignment and to make them adaptable to any changing situation, not only in the life of their country but in the wider world and to enhance teachers commitment to the teaching profession.

\section{Key Curricular Issues in Nigeria Education}

The Nigerian Education has some key curricular issues, Obioma (2007; 1-2) gave the following::

Identification of minimum competencies and aligning them to the methodology of classroom transactions including pedagogical skills needed and instructional materials; linking learning to the world of work of learners in the cultural context; 
emphasis on functional literacy, numeracy and strategic communication skills; infusionof relevant and functional entrepreneurial skills using the relevant subject contents as drivers; consolidationof some contents and subjects in the basic education context thus reducing subject / content overload; the inclusion of strategic life-long skills as well as positive national values, civic, moral, and ethical education as a course of study; infusion of elements of critical thinking and of such emerging issues as HIV / AIDs education, anti corruption studies, capital market studies etc.

\section{Major Trends of Curriculum Changes}

Education globally has developed beyond traditional and crude strategies of teaching students of today are inquisitive and reach to explore, therefore teachers has to also move ahead of them.According to Obanya (2009), Mkpa (2010), Priestly (2011) and Yates (2012) the major trends of changes in the curriculum manifest as:

Global developments which now have significant influence on national and regional curriculum activities, thereis increased emphases on skills and dispositions which are relevant to lifelong learning, employment and social participation and creativity, educational content and teaching-learning materials now appear to be more functional, diversified and operational nature, movement is now towards information and communication technology, low-cost, portable hand held devices for students' use that can be connected through global networks and tailored for specific tasks or application. This advancement in technology is leading to a multitude of approaches that are standing a million of curriculum that caters for the needs of learners worldwide and there is emphasis on the need for teachers to use differentiated curriculum, multiple learning styles and engage in transformational teaching.

\section{Research Questions}

This research attempt to answer the following questions:

1. Does use of ICT and Social Media enhance teaching and learning?

2. Does use of research, innovational skills and critical thinking promotes effective teaching and learning? 


\section{Research Hypotheses}

$\mathrm{H}_{1}$ : There will beno significant relationship between use of ICT and social media and teaching and learning.

$\mathrm{H}_{2}$ : There will be no significant relationship between use of research, innovational skills, critical thinking and effective teaching and learning.

\section{Population, Sample and Sampling Technique}

The population for this study comprised of lecturers of Federal College of Education (Technical), Akoka, Lagos both males and females.

The sample is 60 lecturers. Disproportionate stratified random sampling was adopted for the sample selection.

\section{Data Analysis Techniques}

Chi-square statistic was used to analyze the level of confirmation with the research questions and hypotheses raised. Simple percentage was equally used to analyze the characteristics of the respondents (Asika, 1991).

\section{Result and Discussion of Findings}

Table 1: Use of ICT and social media enhance teaching and learning.

\begin{tabular}{|l|c|c|}
\hline Response & Frequency & Percentage \\
\hline Strongly Agree & 50 & $83 \%$ \\
\hline Agree & 7 & $12 \%$ \\
\hline Disagree & 2 & $3 \%$ \\
\hline $\begin{array}{l}\text { Strongly } \\
\text { Disagree }\end{array}$ & 1 & $2 \%$ \\
\hline Total & $\mathbf{6 0}$ & $\mathbf{1 0 0} \%$ \\
\hline
\end{tabular}

Source: Field work, 2015. 
Table 1 above shows that the reports gathered from the respondents confirms that use of ICT and social media do enhance teaching and learning.

The table shows $83 \%$ and $12 \%$ i.e 50 and 7 respondents strongly agreed and agreed respectively to the fact that use of ICT and social media do enhance teaching and learning. However $3 \%$ and $2 \%$ i.e 2 and 1 respondents respectively disagreed and strongly disagreed.

Table 2: Chi-square computation for hypothesis one: use of ICT and social media enhance teaching and learning.

\begin{tabular}{|c|c|c|c|c|}
\hline $\mathbf{0}$ & $\mathbf{E}$ & $\mathbf{0}-\mathbf{E}$ & $\mathbf{( 0 - E ) ^ { 2 }}$ & $\frac{(\mathbf{0}-\boldsymbol{E})^{\mathbf{2}}}{\boldsymbol{E}}$ \\
\hline 50 & 15.0 & 35.0 & 1225 & 81.67 \\
\hline 7 & 15.0 & 8.0 & 65 & 4.27 \\
\hline 2 & 15.0 & 13.0 & 169 & 11.27 \\
\hline 1 & 15.0 & 14.0 & 196 & 13.07 \\
\hline Total & & & & $\mathbf{1 1 0 . 2 8} / \mathbf{1 5}$ \\
\hline
\end{tabular}

Source: Research data, 2015 (Drawn from table 1).

$110.28 / 15=7.352$

$X^{2}=7.4$

The table computed Chi-square with calculated value of 7.4 and expected value of 15.0 at 0.05 confidence level i.e 0.95 level of significance.

Since $X^{2}$ calculated is less than $X$ critical (expected) alternative hypothesis $\left(H_{1}\right)$ is therefore rejected and the null hypothesis $\left(\mathrm{H}_{0}\right)$ that is use of ICT social media enhance teaching and learning is accepted. 
Table 3: Use of research, innovational skills and critical thinking promotes effective teaching and learning.

\begin{tabular}{|l|c|c|}
\hline Response & Frequency & Percentage \\
\hline Strongly Agree & 52 & $87 \%$ \\
\hline Agree & 6 & $10 \%$ \\
\hline Disagree & 2 & $3 \%$ \\
\hline $\begin{array}{l}\text { Strongly } \\
\text { Disagree }\end{array}$ & - & - \\
\hline Total & $\mathbf{6 0}$ & $\mathbf{1 0 0} \%$ \\
\hline
\end{tabular}

Source: Field work, 2015.

Table 3 shows the report gathered from the respondents on the use of research, innovational skills and critical thinking as skills that promotes effective teaching and learning. $52(87 \%)$ respondents strongly agreed and 6 respondents agreed $(10 \%)$ while $2(3 \%)$ respondents disagreed.

Table 4: Chi-square computation for hypothesis two: Use of research, innovational skills and critical thinking promotes effective teaching and learning.

\begin{tabular}{|c|c|c|c|c|}
\hline $\mathbf{0}$ & $\mathbf{E}$ & $\mathbf{0}-\mathbf{E}$ & $(\mathbf{0}-\mathbf{E})^{\mathbf{2}}$ & $\frac{(\mathbf{0}-\boldsymbol{E})^{\mathbf{2}}}{\boldsymbol{E}}$ \\
\hline 52 & 20.0 & 32 & 1024 & 51.20 \\
\hline 6 & 20.0 & -14 & 196 & 9.8 \\
\hline 2 & 20.0 & -18 & 324 & 16.2 \\
\hline Total & \multicolumn{2}{|l}{} & & $\mathbf{7 7 . 2 0 / 2 0}$ \\
\hline
\end{tabular}

Source: Research Data, 2015 (Drawn from table 3).

$77.20 / 20=3.86$

$X^{2}=3.86$

The table computed Chi-square calculated value of 77.20 and expected value of 20.0 at 0.05 confidence level i.e 0.95 level of significance. 
Since $X^{2}$ calculated is less than $X$ critical expected alternative hypothesis $\left(H_{1}\right)$ is therefore rejected and the null hypothesis $\left(\mathrm{H}_{0}\right)$ that is use of research, innovational skill and critical thinking promotes effective teaching and learning is accepted.

\section{Implications of the Study}

It is evident as shown by the result(s) of the study that use of ICT, research, innovational skills and critical thinking skills promotes and enhance effective teaching and learning in students.

This therefore indicates that the tools are expected ones which any new generation teacher should use in order to facilitate and take teaching to the future it deserves.

\section{Trends for Future Education}

The process of education has moved beyond chalk and marker work in the classroom to advance digitalization and use of ICT together with innovative and critical thinking skills. This is why Tina Barseghian (2011) gave the following as the future trends that will shape the future of curriculum, they are:

- Collaboration: That students are gradually collaborating with each other through social media to learn more about specific subjects, test out ideas and theories, learn pacts and guage each other's opinion.

- Technology Powered: That pen and pencils are far from obsolete but forward drinking educators are finding other interactive tools to grab their students' attention Blended: blended learning is consisting computers with traditional; learning.

\section{Conclusion}

In conclusion, the process of education in Nigeria needs total overhauling and such should also transcend to teacher education programme. Education should be geared towards addressing the current trends in the system, the various curricular issues and likewise the teaching methodologies and strategies which will go a long wayin preparing students sufficiently for the global market. 
The $21^{\text {st }}$ century education was grown from textbook - driven and teacher - centered methodologies to flexible, creative, innovative and learner - centered methodologies.

So therefore there is need for teachers to make a shift from traditional instructional strategies to the new and emergent ones in order to assist learners develop skills for the global market.

\section{Recommendations}

The following are thereby recommended to order to upgrade the teacher education programme to meet up with the newly emerging trends in global education curriculum.

- Teachers should be trained to become multi-skilled in order to utilize multiple instructional strategies to develop learners as global and creative citizens.

- Teachers should seek for more knowledgeable using research for improved teaching and learning.

- Classroom learning should be structured in a way to require sufferent content knowledge, opportunities to practice and reflect on practicum teaching experiences.

- Teachers should focus more on interactive and participatory teaching method which can motivate and engage learners and thereby promote the abilities of participation, interaction, critical thinking and problem solving skills.

- $\quad$ ICT education should be integrated in teacher education curriculum.

Given the fact that education is the bedrock of development of every society and source no system of education can rise above the quality of teachers, it therefore becomes imperatives that the issue of teacher training and its curriculum be handled properly.

\section{References}

Durosaro, D.O. (2006) "Teacher Education in Nigeria: Past, Present and Future Challenges", journal of the Oyo state college of education, Oyo. 13 (1).

Dosumu, G.M. (2003). "Introduction to Teacher Education" (Revised Edition). Dupek Publications and Educational Services. Mushin, Lagos.

Ibukun, W.O. (2004) "Educational Management Theory and Practice". NIEPA Printing Press, Ondo, Nigeria. 
Mkpa, M.A. (2010), "Innovations and issues in primary and teacher education in Nigeria". Journal of Childhood and Primary Education 71, 1-12.

National Policy on Education (2004). $4^{\text {th }}$ Edition, Lagos, NERDC Press.

Obanya, Pai (2009)"Dreaming, Living and Doing Education". Ibadan Education Research and study group, Ibadan, Nigeria.

Obanya, Pai \& Fadoju, Andrew (2008). Evans professional Teacher - Education Series: General Pedagogy; Ibadan, Evans publishers, Nigeria Limited.

Obioma, G.O. (2007). The 9-years basic education curriculum (structure, contents and strategy for implementation): Nigeria experience in educational reforms. Online http://www.ude.sa.edu.at/files/

Osberg D. \& Biesta G. (2008). The emergent curriculum: Navigating a complex course between unguided learning and planned enculturation". Journal of curriculum students. 40:313-328.

Priestley, M. (2011). Schools, teachers and curriculum change: A balancing act: Journal of educational change, 12:1-23. http://dx.doi.org/10.1007/s10833-010-9140-z

Smith, M.K. (2000). Curriculum theory and practice. The encyclopedia of informal education.

Tina Barseghian (2011). The three trends that will shape the future of education. online kqed.orgoproject.org/anthor/tinabarseghian.

Yates, L. (2012). My school, my University, my country, my world, my Google, myself...... What is education for now? AustralianEducation Researcher. 39(3), 259-274. http://dx.doi.org/10.1007/s13384-012-0062-z

Yoloye, E.A. (2009) "Continuous assessment”: A simple guide for teachers; Ibadan: University press plc. 